\title{
Bequests to an Existing Trust - Problems and Suggested Remedies
}

\author{
W.S.McClanahan*
}

To pour, or not to pour: that is the question:
Whether 'tis nobler in the courts to suffer
Some few defeats and win some victories,
Or to take refuge in a score of pages
And spell it out all over in the will?'

Probably many a lawyer has felt like paraphrasing the Bard of Avon, as he walked away from his first lawsuit construing a pour-over will. For this, the most controversial of the current estate planning devices, ${ }^{2}$ has recently taken the center of the stage. ${ }^{3}$ While the attempt to make a gift by will to an existing trust (the so-called pour-over provision) is not wholly new, the widespread use of this device in estate planning has come about

* Member, California and Illinois bars.

1 With apologies to the greatest phrase-maker of them all, William Shakespeare.

2 For general discussions of these devices, see Shattuck \& FarR, AN Estate PlanNise's HANDBOoK $\$ \S 8-25$ (2d ed. 1953) [heremafter cited as SHATtuck \& FarR] ; 1 Polisher, Estate Planning and Estate Tax Saving (2d ed. 1948); Casner, Estate Plannmig (2d ed. 1956); Bowe, Estate Planning and Taxation (1st ed. 1957); Harris, Fammty Estate Planning Gume (1st ed. 1957); 1 Appreman, Basic Estate Planning (1st ed. 1957); Casey, Estate Plans, Institute for Bustness Planning (Looseleaf Service 1958).

${ }^{3}$ For general discussions of the doctrines of incorporation by reference, acts of independent significance and non-testamentary acts, see 1 SCOTT, TRUSTs $\$ 53$ (2d ed. 1956) [hereinafter cited as Scotr] ; ATKINSON, WIIIS $\S 80$ (2d ed. 1953) [hereinafter cited as ATKINSON]; 1 PAGE, WIIIS $§ 249$ (3d ed. 1941) [hereinafter cited as PaGe]; I Bogert, Trusts and Trustees $§ 106$ (2d ed. 1951) [hereinafter cited as BocERT]; THOMPSON, WIILS $\$ 106$ (3d ed. 1947) [hereinafter cited as Thomrsson]; Shatruck \& FarR $\$ 16$. The subject las been discussed in the following articles: Dobie, Testamentary Incorporation by Reference, 3 VA. L. REv. 583 (1916); Evans, Non-Testamentary Acts and Incorporation by Reference, 16 U. CHI. L. REV. 635 (1949); Evans, Incorporation by Reference, Integration and Non-Testamentary Act, 25 CoLUM. L. REv. 879 (1925); Lauritzen, Pour Over Wills, 95 Trusts \& Estates 992 (1956); Lauritzen, Can a Revocable Trust Be Incorporated by Reference?, 45 ILI. L. REv. 583 (1950) ; Palmer, Testamentary Disposition to the Trisstee of an Inter Vivos Trust, 50 MIcH. L. REv. 33 (1951); Scott, Trusts and the Statute of Wills, 43 HaRv. L. REv. 521 (1930); Trachtman, Pour Overs, 97 TrUSTS \& EstaTeS 416 (1958); 57 MrCH. L. Rev. 81 (1958) (a sequel to the article by Palmer cited above); Shircliffe, Testamentary Additions to an Existing Trust, Thesis submitted to the Graduate School of Banking, Rutgers University (1953) (available in the libraries of Rutgers University, Harvard University and The American Bankers Association; also abstracted in american Bankers Association, Present Day Banking 317 (1954)). This thesis contains one of the best available analyses and discussions of the subject and the problems involved and the most complete list of cases, texts and articles to be found. 
almost entirely within the past generation. ${ }^{4}$ In that short time it has engendered considerable strife and litigation and has had a rather checkered career in the courts. Regardless of the problems, it appears that the pourover will is becoming more widely used every day.

\section{The Reasons for Pouring Over}

It is submitted that there are several sound reasons for this common desire of testators and their attorneys to use the pour over device, which might be summarized as follows:

1. To obtain the experience of trustee management, to experiment and improve the instrument which controls the trust, looking on the living trust as a sort of "trial will" during their lifetime. (This would require an amendable or revocable trust.)

2. To avoid publicity concerning family and business plans which is a necessary corollary to drafting those plans into a will which becomes a public record on being admitted to probate.

3. To eliminate the costs of administration (including attorney's fees, executor's commissions and other expenses) on that part of the property transferred to the living trust.

4. To secure professional management and counsel with respect to the property transferred to the living trust, particularly among those estate owners in the later years of life, when the responsibility for management and investment may become a heavy burden to these elderly property owners.

5. To obtain professional management and the flexibility of a modern trust for the proceeds of life insurance policies, rather than having sizable sums paid to individual beneficiaries in cash, or distributed to them over long periods under the usual settlement options available in most life insurance policies.

4 One of the earliest cases involving a writing in the form of a trust was Johnson v. Ball, 5 De G. \& Sm. 85, 64 Eng. Rep. 1029 (Ch. 1851), in which the will referred to a memorandum to trustees "to hold the same upon the uses appointed by letter signed by them and myself." While there were some other early cases, the bulk of the American bitigation has arisen since the decision in the leading case of Atwood v. Rhode Islarid Hospital Trust Co., 275 Fed. 513 (Ist Cir. 1921).

5 Josepl Trachtman, in his recent article, Pour Overs, 97 Trusts \& Estates 416 (1958), has this to say about the prevalence of the practice: "There is a type of estate planner who cannot resist the urge to pour over. The pouring is usually by Will to a living trust created by the testator-settlor, but sometimes the laws of gravity are disregarded and assets are made to flow up instead of down, or laterally-from trust to trust--with the nonchalance of goats who leap froin precipice to precipice. The more frenzied planners do not have the sixth sense or sure-footedness that nature gives to goats, and so sometimes they take these shortcuts without being aware of where they lead." Sce also Hackett, Estate Clinics, 97 Trusts \& Estates 32 (1958). 
6. To reduce or minimize income, estate and inheritance taxes. (In most situations this would require an irrevocable or short term trust.)

7. To simplify the management and administration of the testator's estate by "pouring over" the residue of the probate estate into the existing trust, rather than creating an additional testamentary trust to be administered as a separate entity.

8. To avoid the extra fees, commissions and expenses involved in administering a testamentary trust in those states where such trusts remain under the jurisdiction of the courts and are subject to periodic accountings and reports to such courts.

As the first cases involving this problem came before the courts for review, quite naturally they tried to nieasure and test this device alongside or within the framework of certain doctrines already well known and rather generally accepted in the law of wills. The principal theories chosen for this testing process were the "incorporation by reference," ${ }^{\text {and }}$ ane "independent significance," 7 or "non-testamentary act" doctrines."

Because of the importance of this device in modern estate planning ${ }^{9}$ and its continued use in the face of the difficulties so far encountered, it seems worthwhile to take a critical look at some of the leading cases in this field, to appraise the status of the pour-over will in the law today, and to suggest some solutions which should eliminate the friction between this useful device and sonie of the older concepts in the law of wills.

\section{The Atwood Case}

One of the earhiest reported cases dealing with this question, Atwood $v$. Rhode Island Hospital Trust Company, ${ }^{10}$ is still the leading case in this field. It dealt with an amendable and revocable living trust of nore than $\$ 2,000,000$ in value. On August 14, 1911, a Mr. Davis created a living trust, reserving full powers to amend or revoke, with income payable to the trustor during his lifetine; after his death inconie was to be payable to his wife and another person and, upon the death of the survivor of them, the principal was to be distributed by the trustee to about thirty named bene-

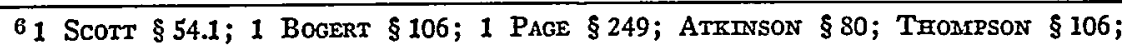
17 MINN. L. REv. 527 (1932).

7 Professor Scott seems to prefer this term. See 1 ScotT $\$ 54.2 ; 1$ Bogert \$ 106; ATKINsov § 81; Scott, Trusts and the Statute of Wills, 43 HARv. L. REv. 521, 546 (1930).

8 Professor Evans seems to prefer this term. See Evans, Incorporation by Reference, Integration and Non-Testamentary Act, 25 CoLUM. L. REv. 879, 891 (1925).

$\checkmark$ While no official figures are available, attorneys and trust officers from many areas have stated to the writer that a large percentage of the estate plans in their areas use the living trust and the pour over will. The fact that twelve states have adopted legislation specifically approving this device in the last five years further indicates its increasing use and growing importance. See also text at note 5 supra.

10275 Fed. 513 (1st Cir. 1921). 
ficiaries. On the same date, but subsequent to signing the trust agreement, Davis executed his will, the residuary clause giving the residue of the estate to the trustee of the living trust to be held, managed and disposed of as part of the principal of that trust. ${ }^{11}$

Davis executed a codicil to his will on October 4,1911, an amendment to the trust agreement on October $5,1911,{ }^{12}$ and a second amendment to the trust on October $17,1913 .{ }^{13}$ He died February 23,1915 . The litigation arose upon the filing of a bill in equity, brought by the executor of his wife's estate and others, seeking to have the residuary clause of the will declared void for indefiniteness.

The court held the attempted gift to the trustee by the residuary clause of the will to be void, relying on an early English case, Johnson v. Ball, ${ }^{14}$ and a Massachusetts case, Olliffe $v$. Wells. ${ }^{15}$ The court stated that the plan of the will and the trust was obnoxious to the statute of wills, quoting from Johnson v. Ball,

A testator cannot by his will prospectively create for himself a power to dispose of his property by an instrument not duly executed as a will or codicil. ${ }^{16}$

Following this the court said, "This is exactly what Davis undertook to do as to the residue of his testamentary estate. This case is on all fours with Olliffe v. Wells," 17 a conclusion which seems erroneous on the facts imvolved. ${ }^{18}$

An interesting sidelight on the Atwood case is that the original plan was later made operative when the Rhode Island Supreme Court held, in

11 The lengthy residuary clause of the will was abbrevinted by the court. The clause directed the executors to pay over the residue to the trustee, "to be held, managed and disposed of as a part of the principal of the estate and property held by it in trust for my lifo and the lives of others in the same manner as though the proceeds of such sales had been deposited by me as a part of said estate. . .." Id. at 520 .

12 This amendment added four beneficiaries to the trust who were to receive at termination from $\$ 5,000$ to $\$ 15,000$ each, a total of $\$ 35,000$.

13 This amendment added one new beneficiary to the trust to receive at termination $\$ 5,000$ and cancelled the provision for one of the original beneficiaries who was to have received $\$ 3,000$.

145 De G. \& Sm. 85, 64 Eng. Rep. 1029 (Ch. 1851).

15130 Mass. 221 (1881).

185 De G. \& Sm. 85, 91, 64 Eng. Rep. 1029, 1032 (Ch. 1851).

17275 Fed. 513, 521 (1st Cir. 1921).

18 In Oliffe v. Wells, the residue was bequeathed to the Reverend Mr. Wclls, "to distribute the same in such manner as in his discretion shall appear best calculated to carry out wishes which I have expressed to him or may express to him." This language fails to satisfy three of the requirements of incorporation. See note 36 infra. It does not refer to a paper or document as already in existence; it could refer to written or oral wishe:; expressed before or after the date of the will; and the reference is not clear and specific enough to identify the paper or writing sought to be incorporated. These facts bear no resembilance to the facts in the Atwood case, which involved a formal, existing trust agreement, positively identified in the will. 
Merrill v. Boal, ${ }^{18}$ that the trust agreement was executed in conformity with the statute of wills and admitted it to probate as part of the will. ${ }^{20}$ Thus the original beneficiaries finally received the property as Davis had planned, but it was fourteen years after his death ${ }^{21}$ and eight lawsuits later $^{22}$ that this costly litigation over one estate finally was laid to rest.

In analyzing the Atwood case, it may be helpful to simplify the facts and see just what the testator-who was also the trustor of the living trust -attempted to do. He created a valid hiving trust, by a carefully prepared written instrument, reserving the right to amend or revoke, with complete provisions for final distribution if it should not be revoked prior to his death, and then transferred and delivered the trust assets to the trustee. He then executed a valid will by which he bequeathed the residue of his estate to the trustee of his living trust, which he correctly and specifically identified, to be held and disposed of under the terms and provisions of the living trust. After this he amended the living trust twice as to the persons to receive property from the living trust at its termination. That was the status at his death.

On the claim that this residuary clause was void for indefiniteness, the court, without preliminary explanation, stated three conclusions which, paraphrased, are:

1. That the clause does not incorporate by reference any existing trust instrument.

2. That, unexplained by parol evidence, the clause is manifestly void for indefiniteness.

3. That the clause is to be construed as covering trust provisions then and thereafter made by the testator.

It is submitted that the court was correct in its conclusions (1) and (3), but was in error as to conclusion (2).

\section{INCORPORATION BY REFERENCE}

It may be well to examine the theory underlying conclusion (1) carefully, since the doctrine of "incorporation by reference" plays such a major role in this problem and enters into almost every opinion of the cases

1047 R.I. 274, 132 Atl. 721 (1926).

$20 \mathrm{It}$ is interesting to note that the trust agreement, while executed with the formalities required by the Rhode Island Statute of Wills, was not in itself a testamentary disposition. Its admission to probate served to validate and clarify the trust created by the will. It appears that this decision could have been based on the doctrine of integration. See text at notes 40,41 infra.

21 The testator died in 1915, the first case reached the reviewing courts in 1918, and the last case was decided in 1929.

22 There were four cases involving this will and trust in the United States Circuit Courts and four in the Supreme Court of Rhode Island, a complete list of this hitigation being cited in 21 A.L.R.2d 220 (1959). 
later discussed. The doctrine that a validly executed will may, by appropriate language, incorporate into the will another paper or document even though the incorporated paper does not satisfy the statutory requirements regarding wills, came into Anglo-American law at an early date. ${ }^{23}$ One can only speculate as to the reasons for it. ${ }^{21}$

The doctrine has had general acceptance in England since prior to the enactment of the Wills Act in $1837 . .^{25} \mathrm{~J}$.t has been accepted in most American jurisdictions, ${ }^{26}$ including California. ${ }^{27}$ The courts in Louisiana, ${ }^{28}$ New Jersey ${ }^{29}$ and New York ${ }^{30}$ have stated that they do not recognize the doctrine, but results quite similar to incorporation have been achieved in some cases in these states, ${ }^{31}$ leaving the asserted rejection in doubt. Only Connecticut ${ }^{32}$ has consistently refused to recognize the doctrine, and that state has now by statute given partial approval to the doctrine as it relates to trust agreenents which meet certain tests as to formality of execution. ${ }^{3 \mathrm{a}}$

A leading Enghish case on the subject of incorporation by reference is Johnson v. Ball, ${ }^{34}$ decided in 1851 shortly after the passage of the Wills Act. ${ }^{35}$ This was the case which was quoted and relied upon in the Atwood case and in many of the leading cases since. Here the will bequeathed an

${ }^{23}$ In has been stated that the earhiest case of incorporation was Molineux v. Molineux, 4 Cro. Jac. 144, 79 Eng. Rep. 126 (1607), cited by Lauritzen, Can a Revocable Trust Be Incorporated by Reference?, 45 Ir工. I. Rev. 583, 585 (1950).

24 Perlaps when literacy was not so common, when wills had to be laboriously written by the lawyer or the scrivener in longhand, both testators and lawyers wished to avoid writing and revising wills that might contain long lists of personal effects, heirlooms and similar articles. A simple solution was to prepare in advance a list of such articles and then, by appropriate language in the will, to incorporate that list or other paper into the will.

251 Jarman, WIIIs 147, 153 (8th ed. 1958); 1 Page \$ 249; Atkinson \$ 80; Allen v. Maddock, 11 Moo. P.C. 427, 14 Eng. Rep. 757 (Ct. App. 1858).

261 PAGE § 249; AtKInson \$80; 17 MINN. I. Rev. 527 (1933); Newton v. Seaman's Friend Society, 130 Mass. 91, 39 Am. Rep. 433 (1881) ; Annots., 21 A.L.R.2d 220, 8 A.L.R.2d 614, 3 A.L.R.2d 628, 144 A.L.R. 714.

27 In the Matter of the Estate of Simon v. Grayson, 15 Cal.2d 531, 102 P.2d 1081 (1940); In the Matter of the Estate of Plumel, 151 Cal. 77, 90 Pac. 192 (1907); In the Matter of the Estate of Willey, 128 Cal. 1, 60 Pac. 471 (1900); In the matter of the Estate of Soher, 78 Cal. 477, 21 Pac. 8 (1889); In the Matter of the Estate of Skerrett, 67 Cal. 585, 8 Pac. 181 (1885); In the Matter of the Estate of Miller, 128 Cal. App. 176, 17 P.2d 181 (1932); In the Matter of the Estate of Atkinson, 110 Cal. App. 499, 294 Pac. 425 (1930).

28 Succession of Ledet, 170 La. 449, 128 So. 273 (1930).

29 Murray v. Lewis, 94 N.J. Eq. 681, 121 Atl. 525 (Ch. 1923).

30 Booth v. Baptist Church, 126 N.Y. 215, 28 N.E. 238 (1891).

31 Hessmer v. Edenborn, 196 La. 575, 199 So. 647 (1940); Swetland v. Swetland, 100 N.J. Eq. 196, 134 Atl. 822 (Ch. 1926); Matter of Rausch, 258 N.Y. 327, 179 N.E. 755 (1932); Matter of Fowles, 222 N.Y. 222, 118 N.E. 611 (1918).

32 Hatheway v. Smith, 79 Conn. 506, 65 Atl. 1058 (1907) ; Bryan v. Bigelow, 77 Conn. 604, 60 Atl. 266 (1905) ; Bryan's Appeal, 77 Colm. 240, 58 Atl. 748 (1905).

33 Conn. Gen. Stat. \$ 45-173 (1958). See notes 143, 146, 152 infra.

845 De G. \& Sm. 85, 64 Eng. Rep. 1029 (Ch. 1851).

351 Vict. 80, c. 26 (1837). 
insurance policy to two trustees "to hold the same upon the uses appointed by letter signed by them and myself." There was no letter in existence at the date the will was executed, February 21, 1844. On August 4, 1845 the testator wrote a letter to his executors merely telling them that he had bequeathed the insurance policy to the trustees, but not stating any terms of a trust or naming beneficiaries. Still later the testator signed a memorandum stating the purposes of the trust and naming beneficiaries. Neither of these papers was executed in conformity to the statute of wills.

The court refused to admit the papers to probate as part of the will, pointing out that, although the language of the will referring to a "letter signed by them and myself", appears to refer to an existing document, yet in fact no such document existed when the will was signed. To admit the documents obviously prepared after the will was signed, would be to receive as part of a will a document prepared subsequent to the will and which was not executed as required by the wills act. The case is sound, since the document sought to be incorporated was not "an existing document" and hence failed to satisfy one of the basic requirements of the doctrine of incorporation by reference. ${ }^{36}$ That is all that the case decided or should have

301 Jararan, Wrils 154 (8th ed. 1951); 1 Page § 250; Thomrpson § 106; Atrinson $\S 80$. See also articles cited in notes $3,6,7$ and 8 supra.

It is submitted that the requirements listed below represent a fair statement of the majority rule for a valid incorporation by reference in the United States today. Three of these requirements must be met by the incorporating document-the will-standing alone:

(1) The reference in the will inust show that the testator intended to incorporate the extrinsic paper or document into the will.

(2) The language of the will must be such that it refers to the extrinsic paper or document as one already in existence at the time of the execution of the will.

(3) The reference in the will must be sufficiently clear, definite and specific so that it identifies the extrinsic paper or document with reasonable certainty.

If the incorporating will meets these requirements, then the paper or document offered for incorporation must meet these two additional requirements:

(a) There must be satisfactory proof that the paper or document offered is the one referred to in the will.

(b) There must be satisfactory proof that the paper or document offered was actually in existence at the time of the execution of the will.

These are the rules which, in theory, determine whether or not an incorporation by reference is valid. In practice the courts often accept less than full comphance with these tests. Sometimes the language of the will does not fully satisfy rule (2). A reference in a will to "a memorandum to be found with my papers," could refer to a memo already made or one to be made in the future. If in fact the memo was in existence at the date the will was executed, it is generally held a vahid incorporation. Probably the most surprising relaxation of these rules is the tendency of the courts to find a valid incorporation by reference where there is no compliance with rule (1), requiring the will to show an intent to incorporate. An analysis of the decisions in more than $\mathbf{5 0}$ of the leading cases in this field discloses only 8 cases in which the language of the will indicates an intent to incorporate. Yet in 23 of these cases the gift is validated under the doctrine of incorporation by reference. The reason for this is not hard to find. In many of these cases the only doctrine on which the gift could be validated was incorporation and to invalidate the 
decided. Had the opinion stopped there, Johnson v. Ball might not have become a leading case, but the court continued,

A testator cannot by his will prospectively create for himself a power to dispose of his property by an instrument not duly executed as a will or codicil. $36 \mathfrak{a}$

This is the quotation relied on in the Atwood case. It seems to inject into this rather common situation a conscious, sinister motive on the part of the testator; a motive not present in this case or in inany of the other cases in which the courts have used this phrase to justify invalidating the gift; a inotive to avoid, or get around, or cheat on the statute of wills.

In another leading Enghish case, Allen v. Maddock, ${ }^{37}$ decided shortly after the Johnson case, the court, on different facts, reached a different conclusion. The testatrix signed her will on December 1, 1851, but it was attested by only one witness and was invalid under the statute of wills. On September 13, 1856, the day before her death, she asked her doctor to prepare a codicil for her and she dictated and he wrote, "This is a Codicil to my Last Will and Testament." The codicil made several additional bequests and was duly signed and attested so that it fully complied with the statute of wills. The question presented to the court was whether the valid codicil sufficiently referred to and identified the invalid will so as to incorporate it by reference.

The court held that this was a valid incorporation and admitted the will and codicil to probate. This was not a specific or complete or perfect identification, but the court deemed it sufficient. The codicil referred to "Iny will" as an existing document, the reference was definite enough so that the document--the invalid will-could be clearly and positively iden-

gift would have caused the entire estate to pass as intestate property. Courts are always reluctant to adopt a construction which will lead to intestacy. Hence the many cases where the courts find an intent to incorporate when the language of the will shows no such intent. This is particularly noticeable in the true "pour-over" cases. In most of these the language of the will and the whole plan of distribution indicate a clear intent and a strong desire not to incorporate the trust agreement. Yet the courts in many cases have held that incorporation was intended and have decided the case on this basis. One of the few courts to note this intent not to incorporate and to base its decision on it, was the Supreme Court of California in Wells Fargo Bank and Union Trust Co. v. Superior Court, 32 Cal. 2d 1, 193 P.2d 721 (1948), noted in 22 So. Catrr. I. Rev. 205 (1949). The court stated, "It is neither necessary nor proper to apply the doctrine of incorporation by reference to a valid and operative inter-vivos trust when the trustor, as in tho present case, expressed no intention in the will or in the inter-vivos trust instrument that the latter be incorporated into the will. The expressed intention of the trustor in both documents was contrary to the theory that he intended to incorporate the trust into his will." 32 Cal. $2 \mathrm{~d}$ at 7,193 P.2d at 724.

36a 5 De G. \& Sm. at 91, 64 Eng. Rep. at 1032.

3711 Moo. P.C. 42 ל, 14 Eng. Rep. 757 (Ct. App. 1858). 
tified by parol evidence; and the court held that such evidence should be admitted to assist in this identification process. ${ }^{38}$

This case contains an extensive review of the rules and authorities on incorporation by reference, both before and after the Wills Act. An interesting aspect of the case is that the court rather apologetically quoted from a handbook for laymen ${ }^{39}$ as correctly stating the rule to be apphed. A reading of this statement may explain why so many testators in England then and since have used this method of disposing of their property.

\section{Integration and REPUblication}

There are two other doctrines in the law of wills which are distinct from the doctrine of incorporation by reference but which, due to their nature, are related to and sometimes overlap this doctrine. These are the doctrines of integration and republication.

Integration is the process of determining what papers or writings actually constitute the will, using the term "will" in its broadest sense, as meaning the entire conscious plan of disposition of the testator as recorded in a writing or writings. ${ }^{40}$ Not all testamentary writings it neatly into the pattern of an obviously integrated, coherent, complete, single writing, bearing all the earmarks of a formal, valid will. Often the courts are called upon to examine several writings and integrate into the will only those which ineet the requirements which have evolved as prerequisites for valid integration.

In general, only those writings can be integrated which were intended by the testator to operate as his will, were present at the time of execution of the will and can be construed to acquire their effect from a single act of execution. ${ }^{41}$ It can be seen that this doctrine of integration often overlaps and sometimes inerges almost imperceptibly with that of incorporation. There are many situations in which the facts would justify making the ex-

88 The lower court received parol evidence from the doctor who wrote the codicil as to what questions he asked the testatrix, what answers the testatrix made and where she said her will would be found; and from several other witnesses, as to the circumstances surrounding the making of the codicil and that the will was actually found in the place the testatrix described. The lower court admitted the will and codicil and the Court of Appeal affirmed.

30 Lord St. Leonard's HANDY BOoK ON ProperTy LAw, quoted by the court, 11 Moo. P.C. at 462, 14 Eng. Rep. at 770: "So a will or codicil not duly executed, may be rendered valid by a later codicil duly executed and referring clearly to it, or in such manner as to show the intention. Therefore, if you were to begin your codicil, 'This is a Codicil to my last Will', and there was only one will, those words would set up the will, although not duly executed."

40 In the Matter of the Estate of Merryfield, 167 Cal. 729, 141 Pac. 259 (1914); In te Swain's Will, 162 N. Car. 213, 78 S.E. 72 (1913); 1 Page § 242; Atrnsson § 79; THoxapson $\S 105$.

41 Note 40 supra. Cole v. Webb, $220 \mathrm{Ky} .817,295$ S.W. 1035 (1927); Appeal of Sleeper, 129 Me. 194, 151 Atl. 150 (1930), 17 VA. L. REv. 69 (1930), 40 YaxE L.J. 144 (1930). 
trinsic or separate paper a part of the will under either the incorporation by reference or the integration doctrine. ${ }^{42}$

The second doctrine which often overlaps incorporation by reference is that of republication. ${ }^{43} \mathrm{~A}$ will which was validly executed and has been revoked, but not physically destroyed, may be republished by a subsequent will or codicil which is validly executed, and whicl indicates that a revival is intended. ${ }^{44}$ It has also been held that an invalid will may be republished by a validly executed codicil. ${ }^{45}$ Professor Atkinson has argued that, strictly speaking, the revival of a will which was never valid cannot be justified on the basis of republication for, "one cannot restore that which has never had life." ${ }^{\prime 46}$ It is in this area that confusion results. Some of the cases which give effect to an invalid will on the basis of republication by codicil could have been justified on the basis of incorporation by reference, ${ }^{47}$ and some of the decisions seein to rest on both doctrines. ${ }^{43}$

Thus the courts had a background of three long accepted doctrinesincorporation by reference, integration, and republication - against which to test the first cases of bequests by will to an existing trust-the pour-over device. It is perhaps unfortunate that the courts felt constrained to try to force this flexible device into the narrow and rigid frameworks of these

12 In the Matter of Skerrett, 67 Cal. 585, 8 Pac. 181 (1885), the testator left a grant deed conveying land to his sister in an envelope, undelivered, and in another envelope a copy of this deed and a letter to his sister stating his intention that she have the land at his death. The deed could not be admitted to probate alone for it was not a testamentary instrument, the letter could not be admitted alone as a holographic will for lack of a date. The court admitted the two documents together, stating, "Neither the copy of the deed nor the letter, taken by itself, constitute a will; the one is not testamentary in its character, the other has no date; but taking them together as the deceased left them, forming one document, it is complete. The first part furnishes the date, the latter the testamentary character." Id. at 588, 8 Pac. at 183. In the Matter of the Estate of Miller, 128 Cal. App. 176, 17 P.2d 181 (1932), two holographic writings were found in possession of the testator, the larger paper referring to the smaller paper which was folded inside it. The court admitted the two writings as a bolographic will, relying on the doctrine of incorporation by reference, but integration would have been a sounder basis for the decision. See also Estate of Atkinson, 110 Cal. App. 499, 294 Pac. 425 (1930) ; Merrill v. Boal, 47 R.I. 274, 132 Atl. 721 (1926).

43 2 Page § 541; Atknsson § 90; Thonspson § 184.

44 California has provided for this result by statute, CAL. Prob. CODE $\$ 25$; Estate of Atkinson, 110 Cal. App. 499, 294 Pac. 425 (1930); Derr v. Derr, 123 Kan. 681, 256 Pac. 800 (1927); Farmers Bank \& Trust Co. v. Harding, 209 Ky. 3, 272 S.W. 3 (1925). See note 43 supra.

15 Rogers v. Agricola, 176 Ark. 287, 8 S.W.2d 26 (1928); In the Matter of the Estate of Baird, 176 Cal. 381, 168 Pac. 561 (1917) ; Barnes v. Phillips, 184 Ind. 415, 111 N.E. 419 (1916); Taft v. Stearns, 234 Mass. 273, 125 N.E. 570 (1920).

${ }^{46}$ ATensson $\S 80$; Evans, Testamentary Republication, 40 HaRv. L. REv. 71 (1926); cf. Allen v. Maddock, 11 Moo. P.C. 427, 14 Eng. Rep. 757 (Ct. App. 1858).

47 Estate of Atkinson, 110 Cal. App. 499, 294 Pac. 425 (1930); Taft v. Stearns, 234 Mass. 273,125 N.E. 570 (1920).

48 Simon v. Grayson, 15 Cal.2d 531, 102 P.2d 1081 (1940); In the Matter of the Estate of Plumel, 151 Cal. 77, 90 Pac. 192 (1907); In the Matter of the Estate of Miller, 128 Cal. App. 176, 17 P.2d 181 (1932). 
historic doctrines. It was inevitable that in many cases the device would not fit, and the expressed intention of the testator would be denied effect. That is exactly what happened in the Atwood case.

The court was not without the benefit of argument that gifts to the trustee of an existing trust should receive different analysis and treatment than those where the documents sought to be incorporated were future instructions of the testator ${ }^{49}$ or instruments "to be prepared." ${ }^{50}$ It was also argued that the gift should be held valid under a fourth theory which has come to be known as the "independent siguificance" or the "non-testamentary act" doctrine. ${ }^{51}$

\section{The Independent Stgnifance Doctrine}

This is not a new doctrine. One of the early applications of it, although not under this name, was in Langdon v. Astor's Executors, ${ }^{52}$ where the

49 Olliffe v. Wells, 130 Mass. 221 (1881). The dissent of Judge Bingham in the Atwood case is a more logical analysis of the case than the inajority opinion. He points out that the formal, written trust in the Atwood case bears no resemblance to the loose language of the will in Olliffe v. Wells, stated in the future tense and referring to "wishes which I may have expressed to him or may express to him." Yet the majority blithely stated, "This case is on all fours with Olliffe v. Wells." See note 17 supra.

50 Keeler v. Merchants Loan and Trust Co., 253 Ill. 528, 97 N.E. 1061 (1912). The majority in the Atwood case seemed so disturbed by the fact that the trust was amendable and revocable by the trustor-testator that they paraphrased the residuary clause thus: "I give the residue of my estate to said Trust Company to be disposed of to such persons and in such proportions as I may have instructed or shall hereafter instruct said Trust Company." 275 Fed. at 521 . In 2 sense, this statement is correct. There is no doubt that Davis intended to give the residue of his estate to the trustee to be held under the terms of the trust as it existed at the date of his death, including the amendments made after the will and codicil were executed. But he intended to give it to the trustee, not to the beneficiaries. That is where the court in the Atwood case failed to see clearly the nature of such a bequest. The court stated, "Manifestly, then, the real disposition of this residuary estate is made, not by the will, but by the shifting provisions of the trust instrument." Ibid. Faulty analyses and careless statenients such as these have clouded the issues and affected the decisions in inany cases through the years.

51 See textbooks and articles cited in note 3 supra. The majority took note of this theory but passed it over with scant attention, preferring to base the decision on the incorporation doctrine. The court acknowledged the argument that, because the trust company had a trust relationship with Davis, the bequest was valid, while if it had no such relationship, as in Olliffe ข. Wells, except that arising by the will, it would not be valid. The court then stated, "In our view, this is a distinction without any legal difference. The real question is whether the residue of this estate was disposed of by Mr. Davis' will. Plainly it was not." 275 Fed. at 523. Again the court seems to have missed the point of the argument. The gift under review was made by the will to the trustee, not by the trust instrument to the beneficiaries. When a will has been admitted to probate, when the trustee named as a legatee in the will has been properly identified, when the executor stands ready to deliver the property to the trustee and the trustee stands ready to receive it, the act of testation is finished; the property has come to rest in tbe hands of the legatee named in the will (the trustee), the will has served its full purpose as a testamentary instrument, the executor and the probate court have fully performed their functions in the administration of the estate; the future ownership and management of the property by the trustee is to be controlled by the terms of the living trust agreement, subject to whatever courts have jurisdiction of such trusts; and that future ownership is not part of the testamentary process which was set in notion when the will was offered for probate.

62 16 N.Y. 9 (1857). 
testator in his will recited a plan to make advancements to certain persons and directed the reduction of the legacies in his will if such advancements were "charged in my books of account." The court allowed evidence of entries in the books of account to be received, including entries made after the execution of the will, to reduce the legacies, on the theory that the advancements and entries were acts of the testator "belonging to the actual business of life" and having a present effect on property regardless of the terms of the will.

Many cases have applied similar tests to gifts by will which were dependent on acts of the testator or others that took place after the will was executed. Dennis v. Holsapple $e^{53}$ validated a gift providing, "whoever shall take good care of me, and maintain, nurse, clothe and furnish me with proper medical treatment . . . shall have all of my property" at death. In Lear v. Manser" the gift was to "the person or persons ... . as shall care for me in my last sickness," and the gift was upheld. In re Reinheimer's Estate $e^{55}$ validated a gift to "the party or parties . . . who may be farming my farm and taking care of me at the time of my death." Abbott v. Lewis ${ }^{50}$ validated a bequest to "the employees of the $O$. J. Lewis Merchantile Company" who had ten years' service with the company at the date of the testator's death. ${ }^{57}$

It will be noted that in these cases the subject matter of the gift, that is, the property (quite often it is the entire residue of the estate) is specifically described in the will-it is the name and identity of the legatee or devisee which is missing. This must be supplied by extrinsic evidencewritten or parol evidence as to who actually cared for the testator, or who actually had ten years' service with the mercantile company at the time of death. In these cases the act which identifies the intended legatee is one in which some third person - the caretaker or the employee-must join with the testator, by accepting the employment and continuing to work, in order to come within the identification test set out in the will. ${ }^{68}$ This is an act

53148 Ind. 297, 47 N.E. 631 (1897).

84114 Me. 342, 96 Atl. 240 (1916).

55 $265 \mathrm{~Pa} .185,108$ Atl. 412 (1919).

5677 N.H. 94, 88 Atl. 98 (1913).

${ }^{57}$ In Stubbs v. Sargon, 2 Keen 255, 48 Eng. Rep. 626 (18.37), affd, 3 Myl. and Cr. 507, 40 Eng. Rep. 1022 (Ch. 1838), a bequest in a will was made "unto and amongst my partners, who shall be in copartnership with me at the time of my decease, or to whoin I may have disposed of my said business. ..." The testatrix disposed of her business during her lifetime and the court received evidence as to the identity of the persons who acquired the business and validated the bequest to them.

${ }^{58}$ Cf. Harriman v. Harriman, 59 N.H. 135 (1879), in which the testator devised a lifo estate in his farm to certain relatives and then devised the remainder to "such person or persong as shall take care of and support (the life tenants) in their old age," and the devise was held valid. Here the acts which would identify the devisee of the land would have to be performed by third persons long after the testator had died and would have to be proved by extrinsic evidence. 
which is likely to be known to many persons in the community, and hence it is not difficut to prove. Yet the fact remains that the testators in the Dennis, Lear, and Reinheimer cases could have discharged or changed their caretakers, and the testator in the Abbott case could have discharged several clerks from his store, after the wills were executed, and thus could have changed the entire distributions of their estates. But the courts have not hesitated to admit extrinsic evidence to identify the legatees and validate the gifts in scores of cases similar to these.

Another line of cases concerns the gift of the contents of a house, room, trunk, or locked chest or other type of container, without any further or specific description of the contents, often referred to as the "box cases," although perhaps a more accurate label would be the "container cases." These cases usually hold that the contents at the date of death pass to the named legatee. ${ }^{59}$ It will be noted that in this class of cases the name and identity of the person who is to receive the gift is fully set out in the willit is the nature and amount of the gift which is not specified. This must be supplied by extrinsic evidence-evidence as to what the room or trunk or chest actually contained at the date of death-a fact which the courts have said has independent significance or significance apart fron its testainentary effect. ${ }^{60}$ Again the courts have seen no particular difficulty or danger in the fact that the testator could vary the bequest by his own unwitnessed act, as often as he wished, after the execution of his will, by the simple process of removing the furnishings from the house or room, or removing the cash or jewelry or securities froin the trunk, chest, or container. On the theory that these acts had independent legal significance, the courts have generally validated this type of gift.

As the cases involving gifts by will to a formal, written, existing trust - the true pour-over cases-began to come up for review, the courts naturally reached for precedents among these long established doctrines. In nearly all of these cases incorporation by reference was urged as one of the grounds for upholding the gift. In many of the cases the doctrines of integration, republication, independent significance or non-testamentary act have also been argued or have been adopted by the courts as a basis for the decisions.

69 Arknssos § 81. Buchwald v. Buchwald, 175 Md. 103, 199 Atl. 795 (1938); Gaff v. Cornwallis, 219 Mass. 226, 106 N.E. 860 (1914); cf. Fastings v. Bridge, 86 N.H. 247, 166 Atl. 273 (1933); In the Matter of Thompson, 217 N.Y. 111, 111 N.E. 762 (1916).

60 Professor Atkinson has pointed out that in fact a testator might perform one of these future acts (such as discharging a servant or removing the contents of a safe deposit box) with the primary purpose of affecting the disposition of his property. ATKIvsoN $\$ 81$. This point does not seem to have bothered the courts because such acts normally have significance quite apart from their effect on the will. 


\section{The Earix Pour-Over Cases}

One of the first cases involving a formal trust was In the Matter of the Estate of Willey, ${ }^{61}$ decided in California in 1900. In this case the testator had executed and delivered a deed of trust conveying all his lands to trustees for purposes set forth fully in the deed. Three days later he executed a properly attested will which devised and bequeated all of his property to these same trustees "in trust, however, for the uses and purposes set forth and declared in" a certain deed of trust. The trust was fully revocable by the trustor (testator) during his lifetime, but had not been amended or revoked at the time of his death four months later. ${ }^{62}$ The court held that the necessary requirements for incorporation by reference were present and that the gift was valid. ${ }^{63}$

No other cases involving gifts to formal, written trusts seem to have come up for review until the Atwood case in 1921, previously discussed. The next case of importance was the New Jersey decision, Swetland $v$. Swetland, ${ }^{\text {b4 }}$ in which it was held that a gift by will to an existing trust was valid, "[R]egardless of what the rule is in New Jersey with respect to the doctrime of incorporation by reference." This opinion points out with clarity the basis on which the doctrine of independent significance rests. ${ }^{80}$ In Linney v. Cleveland Trust Company, ${ }^{67}$ the gift by will was to the trustees of a community charitable trust created by a resolution of the directors of the trust company and it was held valid.

In Matter v. Rausch, ${ }^{68}$ the Court of Appeals of New York was called

01128 Cal. 1, 60 Pac. 471 (1900).

62 The lower court had refused to allow the incorporation of the deed of trust on tho ground that it was not present when the will was executed. This is another instance of the confusion by the courts of the requirements of the doctrine of integration with those of incorporation.

83 This case is criticized in Lauritzen, Can a Revocable Trust Be Incorporated by Reference?, 45 Ir工. L. REv. 583, 596 (1950). It is stated, "The court never discussed the problem created by the revocable nature of the incorporated trust, ancl apparently this question was never presented by counsel." This comment seems strange since the court stated that "The reserved right to revoke was mere privilege and, as it was never exercised, it had no effect upon the estate granted." 128 Cal. at 9,60 Pac. at 473. Actually the case seeins to have been well argued as the court rather wearily complains, at 6 , that the briefs of the respondent (opposing the incorporation) consist of several hundred pages, many points and innumerable authoritics cited.

64102 N.J. Eq. 294, 140 Atl. 279 (Ct. Err. \& App. 1928).

$65 \mathrm{Id}$. at 296, $140 \mathrm{Atl}$. at 279 . New Jersey has been considered generally as one of the few states which does not accept the doctrine of incorporation by reference. Note 29 sitpra.

66 "The trust to which this bequest is added is not theoretical, nebulous, intangible or incapable of identification, but exists in fact, and the trustee legatee is as distinct and definite an entity as would have been an individual or corporation legatee." Id. at 297, 140 Atl. at 279.

6730 Ohio App. 345, 165 N.E. 101 (1928).

68258 N.Y. 327,179 N.E. 755 (1932). In this case the trust was irrevacable and unamendable. 
upon to rule on the validity of a gift by will to an existing trust and the gift was upheld, although the court did not state specifically on which theory it based its decision. While paying some obeisance to the court's previous insistence that the doctrine of incorporation by reference is not accepted in New York, Judge Cardozo casts some doubt on this rule. ${ }^{60}$ In discussing the theory of independent significance, he also explains one of the bases for the acceptance of this theory in a phrase that has often been quoted in later cases:

Here the extrinsic fact, identifying and explaining the gift already made, is as impersonal and enduring as the inscription on a monument..$^{70}$

In the past twenty-five years the problem of gifts by will to existing trusts has come before the reviewing courts with increasing frequency ${ }^{71}$ and the results have been far from uniform. In spite of this, testators and their attorneys have continued to employ this useful device in their estate plans. It is a fact well known to those in the estate planning field that there are hterally scores of thousands of pour-over wills which will some day be presented for probate and, no doubt, many of these will be questioned and may reach the reviewing courts. It, therefore, seems worthwhile to examine the current status of the law and the several problems involved, and to suggest some possible solutions.

\section{The Factual Situations Analyzed}

Of course the problems presented will vary with the factual situations involved. In analyzing these problems, it should be helpful to set out the most common factual situations which have been or may be presented to

69 "Even in courts where incorporation is permitted more liberally than it is with us, the reference must be to a document or something equivalent thereto...." Id. at 332,179 N.E. at 756. In this case the will contained language indicating a specific intent to incorporate the trust instrument: "[A]nd which agreement is hereby made part of this my will, as if fully set forth herein." Id. at 330, 179 N.E. at 755. Yet the decision seems to be based on the doctrine of independent significance.

70 The court in this case comes close to what is the true relation of a pour-over will and a living trust (at least as to irrevocable trusts), and what the result should be in such cases. It stated, "At the execution of this will there was in existence a valid deed of trust whereby a trustee was under a duty to apply the subject matter of the grant to uses there declared. All that the later will does is to give additional property to the same trustee to be held in the same way." Id. at 330,179 N.E. at 756. See the analysis of this and the later New York cases in Trachtunan, Pour-Overs, 97 Trusts \& Estates 416 (1958).

71 Since 1932 more than twenty-five cases involving gifts by will to existing trusts have reached the reviewing courts in the Umited States. See Scotr § 54.1; Atrnoson \& 80; Lauritzen, Pour-Over Wills, 95 Trusts \& Estates 992 (1956); Scott, Pouring Over, 97 Trusts \& EsTates 189 (1958); Trachtman, Pour-Overs, 97 Trusts \& Estates 416 (1958); Note, Testamentary Nature of Revocable Inter Vivos and Life Insurance Trusts, 1956 WIs. L. REv. 313 (1956); 57 Mrce. L. REv. 81 (1958). 
the courts for review, ${ }^{72}$ to see what the courts have decided in the cases reviewed, and to determine what attitude the courts may or should take as cases involving these and other situations come up for review.

1. An irrevocable living trust, not subject to amendment or change, with a will dated and executed after the creation of the trust, which specifically and adequately incorporates the living trust agreement by reference.

This situation satifies all of the traditional requirements of the doctrine of incorporation by reference. In those states which allow the incorporation by reference of letters, memoranda and other unattested documents into wills ${ }^{73}$, there is no reason why a court should refuse to validate the incorporation of an irrevocable living trust into a will. This appears to have been the situation in the leading case of Matter of Rausch, ${ }^{74}$ and the court validated the gift. The language of the will in that case indicated a specific intent to incorporate the living trust agreement, although the decision seems to be based largely on the doctrime of independent significance.

2. An irrevocable living trust, not subject to amendment or change, with a will dated and executed after the creation of the trust, which devises and bequeaths property to the living trust (or the trustee), with an adequate identification of the living trust in the will.

Here all of the requirements of the doctrine of independent significance, or the non-testamentary act theory, are met.. The living trust, standing alone, certainly has independent legal significance. ${ }^{75}$ The fact that the trust is irrevocable and unamendable gives it the character so aptly described in Judge Cardozo's famous phrase, "as impersonal and enduring as the inscription on a monument."76 It is submitted that a gift by will to such a trust should be upheld in any jurisdiction, without regard to the attitude of the courts toward incorporation by reference. ${ }^{77}$

72 Although most treatments of this subject include a discussion of the cases in which a gift by will is made to a testamentary trust created by another will, or one will incorporates the terms of another, this discussion is limited to gifts by will to living trusts. For cases involving wills of other persons see Bemis v. Fletcher, $23^{\prime} 1$ Mass. 178, 146 N.E. 277 (1925); Condit v. De Hart, 62 N.J.L. 78, 40 Atl. 776 (Ct. Err. \& App. 1898) ; Matter of Fowles, 222 N.Y. 222, 118 N.E. 611 (1918); In the Matter of Piffard, 111 N.Y. 410, 18 N.E. 718 (1888).

73 See text at notes 26 to 31 supra.

74258 N.Y. 327,179 N.E. 755 (1932).

75 The trust was created by the conscious acts of the trustor, before the execution of the will and without reference to it. The series of acts which created the living trust effected a present transfer of the title to property from the trustor to the trustee and created legal relationships between the trustor, trustee and beneficiary which are enforceable in a court of equity; in other words, these acts have true independent legal significance.

76 Matter of Rausch, 258 N.Y. 327, 332, 179 N.E. 755, 756 (1932).

771 Scotr \& 54.3. 
3. A revocable and amendable living trust, with a will dated and executed after the creation of the trust, which specifically and adequately incorporates the living trust agreement by reference.

\section{a. where the living trust has not been amended after the execution of the will.}

When the facts are changed by the reservation of the power to amend or revoke the living trust, the courts and the legal writers have experienced difficulty in validating the bequest under the incorporation by reference doctrine. Yet in this situation the document sought to be incorporated, the living trust agreement, satisfies all of the requirements of the doctrine. The mere fact that the testator-trustor could have changed the ultimate disposition of his property by amending the living trust agreement after the will was executed has no bearing whatever on the doctrine. The document-the trust agreement-is in exactly the same condition at the date of death as it was on the date the will was executed. The court should validate the incorporation ${ }^{78}$ as readily as courts have done where the incorporated documents were deeds, invalid wills, books of instructions, memoranda, letters and lists of articles. ${ }^{79}$

\section{b. where the living trust has been amended after the execution of the will.}

In this situation the courts and writers have experienced more serious difficulty in validating the bequests under the incorporation by reference doctrine, and with more logical reasons. Looking at the trust agreement and the amendment or amendments made after the will was executed as one continuous, coherent, integrated "document," that "document" was not in fact in existence at the date the will was executed. In theory, one of

78 Incorporation was allowed in full in the following cases: Montgomery v. Blankenship, 217 Ark. 357, 230 S.W.2d 51 (1950); In the Matter of the Estate of Willey, 128 Cal. 1, 60 Pac. 471 (1900); In re Snyders Will, 125 N.Y.S.2d 459 (Surr. Ct. 1953) ; Linney v. Cleveland Trust Co., 30 Ohio App. 345, 165 N.E. 101 (1928) ; and in part in Bolles v. Toledo Trust Co., 144 Ohio St. 195, 58 N.E.2d 381 (1944). Contra, In re Jones, [1942] 1 Ch. 328, 1 All E.R. 642. In this latter case the court held that it could not admit evidence as to whether the trust agreement had been amended or not and bence refused to validate the incorporation, although counsel for the trustee stated in his argument that the agreement had not been amended. Palmer, Testamentary Disposition to the Trustee of an Inter Vivos Trust, 50 Mrcr. L. REv. 33 (1951), severely criticizes this narrow view as to the admission of evidence in such cases, stating that "it is difficult to know how to deal with such refined nonsense." Id. at 41.

${ }^{70}$ See notes 26 to 31 supra. Reasoning by analogy from the older cases it is apparent that in all of these cases the testator had the power to revoke the incorporated document. If a testator has properly incorporated a letter or memorandum or list of articles into his will, he certainly has the power to revoke that incorporation at any time prior to death by cancelling or destroying the letter or memorandum. If in fact he has not so revoked it, the courts almost umiversally allow the incorporation. It is difficult to see why a formal trust agreement does not receive the same acceptance as these less formal papers. 
the requirements laid down to be met by the incorporated document is absent; the document was not in fact in existence at the time the will was executed..$^{80}$

The courts have invalidated attempts to incorporate such documents on the basis that, by amending the trust agreement, the testalor-trustor has attempted to dispose of his property at death by an instrument-the amendment-which does not satisfy the requirements of the statute of wills. ${ }^{81}$ As a practical matter, the testator-trustor may not have changed the plan of distribution of his property at all, or only in a minor or inconsequential way. ${ }^{82}$ If the amendment removed one person as the sole beneficiary and substituted another person, the argument might be sound. But suppose the amendment deleted a small gift to one of several beneficiaries who had predeceased the testator and divided this gift among the several remaining beneficiaries, or merely changed the trustor's privilege of directing investment to a veto power over the trustee's recommendations. Should this also be viewed as a change in the disposition of property without satisfying the requirements of the statute of wills? ${ }^{83}$

c. where the living trust has been amended after the execution of the will, and then a codicil republishing the will is executed after the amendment of the living trust.

If it is held that the attempted incorporation under (3) (b) above should fail for the reasons there stated, should the additional element present here cure the defect? It is generally held that the execulion of a valid codicil republishes the entire will and brings it down to the date of the

80 See note 36 supra.

81 Atwood v. Rhode Island Hospital Trust Co., 275 Fed. 513 (1st Cir. 1921) ; President and Directors of Manhattan Co. v. Janowitz, 260 App. Div, 174, 21 N.Y.S.2d 232 (2d Dep't 1940).

82 In the Janowitz case, supra note 81, the only amendment made after the will was executed removed one beneficiary and substituted another, and it is assumed there were several beneficiaries since their interests were stated in thousandths. $C$. Matter of Ivie, 155 N.Y.S.2d 544 (Surr. Ct. 1956), where the later amendments merely changed a successor trustee and eliminated the power of revocation, and the gift was validated.

83 If the rules and requirements of incorporation are followed to their logical conclusion, the answer would be yes, for if the instrument is anended even in the most minor way it is not in exactly the saine condition at death as it was when the will was executed. Some courts have not taken such a narrow view. In Koeninger v. Toledo Trust Co., 49 Ohio App. 490, 197 N.E. 419 (1934), the testator amended his living trust, after his will was executed, by adding one beneficiary to receive $\$ 500$ and another to receive a parcel of land. The $\$ 500$ could be paid from assets contained in the living trust prior to death, but the land had to come to the trustee through the estate of the testator after death. The court allowed the incorporation of the trust and gave effect to the amendment as it related to the $\$ 500$ gift which could be paid froin assets contained in the trust at death, but refused to give effect to the amendment as it related to the gift of land coming by will from the estate. Cf. In re Edwards' Will Trusts [1948] Ch. 440, which gave partial effect to the incorporation of an amended trust; Strause $v$. First National Bank, 312 Ky. 405, 245 S.W.2d 914 (1951). 
republication as though originally executed at that date. ${ }^{84}$ Under this theory, the trust agreement and amendment or amendments were in fact in existence at the date of the execution of the will-i.e., the date the will was republished by the codicil. Simon $v$. Grayson ${ }^{85}$ held that, where a will described a document to be incorporated, which was not in fact in existence at the date the will was executed but was in existence when the codicil was executed, the incorporation was valid. It is submitted that the rule should be the same where the amendments to the living trust are made after the execution of the will but before the execution of the codicil. ${ }^{86}$

\section{$d$. where the living trust has been completely revoked or has terminated after the execution of the will.}

It would seem that this situation should present little difficulty to the courts and writers. Here the trust agreement no longer exists at all, at least as a document which presently controls the admimistration or disposition of property. ${ }^{87}$ If it has been revoked by the volitional act of the trustor, then it should be looked upon as if it had never existed. It is scarcely conceivable that a testator would intend to incorporate such a document into his will. Yet, in Fifth-Third Union Trust Company v. Wilensky, ${ }^{88}$ the court lield valid a gift to a revoked trust on the theory of incorporation by reference, although the language of the will indicated no intention to incorporate the trust agreement. ${ }^{89} \mathrm{It}$ is difficult to rationalize the incorporation by reference of a revoked and nullified document such as the one in this case. ${ }^{.0}$ Likewise it would seem inconsistent to validate such a bequest on the independent significance theory, where the trust has ceased to have any independent significance apart from its effect upon the will at death.

\section{A revocable and amendable living trust, with a will dated and executed} after the creation of the trust, which devises and bequeaths property to

84 See text at notes 44,45 supra.

8515 Cal.2d 531, 102 P.2d 1081 (1940).

86 First-Central Trust Co. v. Claflin, 49 Ohio App. 29, 73 N.E.2d 388 (1947).

${ }^{87}$ No cases have been found in which a trust has terminated, by its terms or otherwise, as distinguished from revocation.

8879 Ohio App. 73, 70 N.E.2d 920 (1946). In this case the trust agreement was executed with all the formalities required for a will.

89 The will devised and bequeathed the residue of the estate as follows: "[T]० the Fifth Third Union Trust Co. as trustee under a certain trust agreement entered into on the 10th day of September, 1931." Id. at 74, 70 N.E.2d at 920.

80 The Ohio courts have consistently based their decisions on the incorporation by reference doctrine, probably because of a specific statute approving incorporation, OrIo GEx. CODE § 10504-4 (1940). The court reasoned that the will had incorporated the living trust agreement (which was executed with the formahty of a will), at the date of execution of the will, which then became part of the testamentary disposition; the revocation was not executed with the formality of a will. Therefore, although the revoking document could operate to revoke the living trust, it could not operate to revoke the terms of the trust as already incorporated into the will. 
the living trust (or the trustee), with an adequate identifiaction of the living trust in the will.

a. where the living trust has not been amended after the execution of the will.

Here we leave the doctrine of incorporation by reference and examine some factual situations which more properly invoke the doctrine of independent significance or the non-testamentary act theory. In these situations the will contains no language showing a specific intent to incorporate any extrinsic document or paper. In a large majority of the reported cases, the language which makes the bequest or devise to the trustee of the living trust or to the trust itself seems to negative any intent to incorporate. ${ }^{01}$ The language of the bequeathing and devising clause generally identifies the trustee by name and the trust agreement by date for the apparent purpose of identification only.

It seems clear that the gift should be upleld in this situation. Here we have a real fact of independent legal significance-the existing living trust. ${ }^{92}$ It is difficult to see how such a trust can be looked upon except as being a fact, or an event, or an entity having real, independent, legal significance apart from any effect that it may liave upon the will or that the will may have upon it. ${ }^{03}$ This being so, it is submitted that a gift by will to the trustee of an existing trust under the facts of this situation should be validated and approved by the court, regardless of the rules of the jurisdiction as to the doctrine of incorporation by reference. ${ }^{94}$

01 In State ex rel. Citizens National Bank v. Superior Court, 236 Ind. 135, 138 N.E.2d 900 (1956), one of the most recent cases validating a pour-over, the residue was devised and bequeathed to "Citizens National Bank ... a trustee, to be held by it under and in accordance with the terms of a certain trust agreement leretofore entered into this day by and between said bank and myself. ..." Id. at 903.

92 The trustee holds title to and possession of the trust property, has the duties and obligations of a trustee to administer the trust property under the terms of the trust instrument and the local laws relating to trusts, owes duties to the trustor and the beneficiaries to render accountings, to distribute or to accumulate the income and to distribute the principal or corpus at termination or upon revocation, all as provided under the terms of the trust agreement; and these duties are presently in effect, continuing and binding and are enforce. able in equity. Also, these duties and legal relationslips are in existence and will remain so under the trust agreement whether the testator-trustor makes gifts of other property to the trustee by his will, makes a completely different disposition of his other property by will or dies intestate.

931 Scort $\$ 54.3$, commenting on Swetland v. Swetland (note 64 supra): "It is submitted that this decision is sound. The Trust created inter vivos was a valid trust existing in fact and independently of the testamentary disposition."

94 Palmer, Testamentary Disposition to the Trustee of an Inter Vivos Trust, 50 Micr. I. REv. 33, 44 (1951), commenting on the Atwood case: "In addition, such a bequest should be upleld on the ground that the instrument las independent significance. This theory is applicable where the trust is not amendable and the independent significance of the writing is in no way lessened by the fact that the terms of the writing were subject to change." See also 1 Scorr \$ 54.3 . 


\section{b. where the living trust has been amended after the execution of the will.}

Where the revocable and amendable trust has been amended after the execution of the will, the courts and writers have experienced more serious difficulty in rationalizing the cases and they are in hopeless conflict. ${ }^{95}$ When an amended trust comes up for scrutiny under the doctrine of incorporation by reference, a strong argument can be made against its incorporation, for the trust agreement is not in exactly the same form at death as it was at the date the will was executed, hence it does not satisfy the second requirement of an incorporated document. ${ }^{96}$

No such barrier should exist under the doctrine of independent significance. Even though the trust has been amended several times, even though the amendments may have changed the administrative provisions of the trust and the ultimate distribution of the trust property in a major way, these facts alone should not stand in the way of validating the gift..$^{97}$

It is in this area that the courts have experienced the most difficulty. In Atwood v. Rhode Island Hospital Trust Company, ${ }^{98}$ the trust agreement had been amended twice after the execution of the will and the court invalidated the gift. Koeninger $v$. Toledo Trust Company, ${ }^{90}$ held that the gift to an amended trust was valid but, following the incorporation doctrine, also held that the amendment made after the will could have no effect on the property received by will. In Old Colony Trust Company v. Cleveland ${ }^{100}$ the court held that the gift to the trust was valid, but that the terms of the trust at the date the will was executed-excluding the later amendment-would control the property received by will. ${ }^{101}$

95 Professor Scott, note 93 supra, and Professor Palmer, note 94 supra, generally favor the pour-over device and believe that the decided cases bave evolved and are evolving a sound body of case law on which gifts to either irrevocable and unamendable or to revocable and amendable trusts can be upheld without doing violence to the statute of wills or other legal principles in this area. Some other writers do not agree. For a hypercritical analysis of the cases and a presentation of a negative viewpoint on this whole subject, see the two articles by Lauritzen in note 3 supra.

${ }^{96}$ See text at note 80 supra.

07 Swetland v. Swetland, 102 N.J. Eq. 294, 140 Atl. 279 (Ct. Err. \& App. 1928) ; Matter of Ivie, 155 N.Y.S.2d 544 (Surr. Ct. 1956). Contra, President and Directors of Manhattan Co. v. Janowitz, 260 App. Div. 174, 21 N.Y.S.2d 232 (2d Dep't 1940). In the Janowitz case the court refused to uphold the gift on the doctrine of independent significance, stating, "The reservation of power to amend the trust indenture and its repeated exercise eliminated all independent significance that might be attached to the trust indenture." Id. at 179, 21 N.Y.S.2d at 287 . This is a rather peculiar viewpoint, since the trust was amended only once after the will was executed, although it had been amended three times prior to the execution of the will.

98275 Fed. 513 (1st Cir. 1921) (see text at notes 12-13 supra).

9849 Ohio App. 490, 197 N.E. 419 (1934) (see note 83 supra).

100291 Mass. 380, 196 N.E. 920 (1935).

101 This is a practical solution to a difficult problem. The court stated, "The will gave the residue to the trustee upon the trusts originally defined and did not purport to do otherwise." $I d$, at 382, 196 N.E. at 921 . Having found this intention, the gift can then be validated on either the incorporation by reference or the independent significance doctrine. Yet in many, 


\section{c. where the living trust has been amended after the execution of the will, and then a codicil republishing the will is excuted after the amend- ment of the living trust.}

This situation should cause less difficulty than that just discussed. The doctrine that a valid will is republished by a. valid codicil and speaks as of the date of the codicil is well settled in the law of wills. ${ }^{102}$ Under this doctrine, the will and codicil would be read as one instrument at the date of the codicil and at that date the living trust, as amended, was in existence. It would seem that the same rule should be applied by the courts in this situation as in those cases where no amendments of the trust agreement had been made after the execution of the will..$^{103}$

In First-Central Trust Company v. Clafin, ${ }^{104}$ the living trust agreement had been amended many times over a twenty year period from 1925 to 1945 . The will was dated August 16,1941, the last amendment to the trust agreement was dated June 27, 1945, and the codicil was dated August 17, 1945. The court held that the gift was vahd, basing its clecision on the doctrine of mcorporation. In re York's Estate, ${ }^{105}$ also involved an amended trust with a codicil executed after the amendments and reciting the dates of the amendments and the court upheld the bequest to the trustees on the basis of the independent significant doctrine. ${ }^{108}$ Another case which upheld a gift to the trustee of an amended living trust, where a codicil was executed after the several amendments, was Continental Illinois Nat'l Bank v. Art Institute of Chicago. ${ }^{107}$ Here the court specifically refused to pass on the question of the validity of the incorporation of a revocable living trust, apparently basing its decision on the independent significance doctrine. ${ }^{108}$

if not most, of the cases there is no language in the will to indicate that the testator intended this result and, more probably, he intended the terms of the trust at the date of death to control the property received by will.

102 Notes 44, 45 supra and accompanying text.

103 Note 78 supra.

10449 Ohio App. 21, N.E. 2d 388 (1947).

10595 N.H. 435, 65 A.2d 282 (1949).

108 The court stated, "However, the proposed disposition is equally sustainable according to the view that the inter vivos trust is a fact "having significance apart froin the disposition of the property bequeathed', which may be rehed upon to control such disposition without violation of the Statute of Wills." Id. at 437, 65 A.2d at 283.

107409 Ill. 481, 100 N.E. 2d 625 (1951). The court recognized the intention of the testator to have the property held and administered under the trust as it existed at the date of death, stating, "clearly, the intention of the testator was to give the residue of his estate to the trustee to be administered under the terms of the trust as amended from time to time." Id. at 491,100 N.E. 2 d at 630.

108 This case presents one of the practical problems in this area of amending a trust and executing codicils to the will after each amendment. The trustor had made seven amendments to the trust agreement, most of them referring to the previous amendments by datc. In the 
In those states which have allowed gifts by will to revocable and amendable trusts which had not been amended, gifts to amended trusts should also be validated if a codicil is executed after the last amendment to the living trust. ${ }^{100}$

\section{d. where the living trust has been completely revoked or has terminated after the execution of the will.}

This situation probably presents the most difficult problems that will be met in this field. As was stated under Paragraph 3 (d) above, the attempted gift cannot be upheld on the independent significance doctrine, for the trust has ceased to have any independent legal significance. It is no longer an existing legal relationship or arrangement which controls property and fixes rights and duties of the parties which can be enforced in the courts.

Likewise, it is difficult to rationalize the incorporation by reference of such a document. The actual document-the piece of paper embodying the trust agreement-may still be available; it could be referred to by the court to determine what were the original terms of the living trust as was done in the Wilensky case. ${ }^{110}$ But it seems to stretch the principles of construction to the limit to presume that the testator intended to incorporate the trust instrument into his will under these circumstances.

It would be comfortable to think that such a situation will not happen, but it has arisen once and it will probably arise again. So long as property owners are careless or forgetful or not properly advised there will be some who revoke their living trusts ${ }^{111}$ or allow them to terminate ${ }^{112}$ without changing their wills to fit the new state of facts.

last amendment to the trust agreement, executed September 7, 1945, and in the codicil to the will, executed the same date, he referred to all previous amendments by date, except the amendment of February 19, 1936, which was inadvertently omitted. The litigation concerned the effect of this failure to mention this one amendment in ratifying the previous amendments by listing them in the last amendment and the last codicil.

100 Notes 91, 93, 94 supra and accompanying text.

110 Note 88 supra.

111 Perhaps a hypothetical situation involving a revoked trust will serve to point up one of the many sets of facts which can and may arise in this area: RICHARD ROE, in 1948, created a revocable living trust of $\$ 50,000$ for his son CharLEs, age 14, with provisions for the income to accumulate until the son was 18 and then to be distributed to him until age 25 and then the principal was to be distributed to the son and the trust was to terminate. In 1954 DAvm ROE, father of RICEARD and grandfather of CHARLES, made his will bequeathing $\$ 50,000$ to the trustee of the 1948 living trust and making similar provisions for six other grandchildren by way of testamentary trusts for them. By the time Criardes was age 21 in 1955 le had been expelled from three colleges, become a confirmed alcoholic and was serving a term for automobile theft. The father, RICEARD, in disillusionment and frustration, revoled the 1948 living trust and made gifts of the $\$ 50,000$ to his other son and daughter. All of this news was kept 
It can be argued that this specific problem will so rarely occur and that there is so little experience with it that it is not a proper subject for legislative action; that justice will be better served by leaving this area to the courts to decide by testing each set of facts and attempting to determine the probable intent of the testator in each case. ${ }^{113} \mathrm{It}$ is submitted

from the grandfather, DAvm, who was in frail health, and he died in 1956 without having changed his will.

If the attempted gift were beld ineffective, there are at least three solutions which might be considered:

(1) Should it descend as intestate property to the grandfather's (Davw's) heirs at law (his son RICHARD and four grandchildren, the children of two deceased sons)?

(2) If the court should find from the language of the will an intent to incorporate by reference the 1948 trust agreement, should the agreement (although no longer effective as a living trust) be incorporated into the will as a written instrument, thus creating a testamentary trust on the same terms for the grandson, CHARIES?

(3) Should a statute provide that the property which was the subject of the ineffective gift be distributed to the person who received the property from the living trust on revocation (in this case the trustor, the testator's son, RICHARD)?

There is little case law in this situation. The Wilensky case adopted solution (2). Six of the twelve statutes discussed below, provide that revocation invalidates the gift, but none furnishes a solution to these three problems.

112 Perhaps another hypothetical situation involving a terninated trust will further point up the problems inherent in such a case: Marx DoE, a widow, in 1948 created a revocable living trust for her daughter Saldy, age 15. Income was payable to or for the benefit of Sally until she should reach age 25 , at which time the trust was to terminate and the principal was to be distributed to SALIx. JoHN DOE, brother of MARY and a bachelor, knowing of the trust for his favorite niece SALIX, in 1949 made his will bequeathing the residue of his estate to the trustee of the 1948 living trust for Salzy. On March 1, 1958, Saliz became 25 years of age, the living trust terminated by its terms and the principal of the trust was distributed to her. JoHN, not remembermg the exact date his niece would reach age 25 , never made any changes in his will and died on May 1, 1958.

If such a gift were held ineffective, there are at least three possible solutions here also:

(1) Should it descend as intestate property to the testator's (JoHs's) heirs at law (including his sister MARY and four brothers, all well fixed financially, but not including his niece SarLY)?

(2) If the court should find from the language of the will an intent to incorporate by reference the 1948 trust agreement, should the agreement (although no longer effcctive as a living trust) be incorporated into the will as a written instrument, thus creating a testamentary trust on the same terms for the miece, SALIX?

(3) Should a statute provide that the property which was the subject: of the ineffective gift be distributed to the person who received the property from the living trust at termination (the testator's niece SAIIY)?

No cases have been found involving terminated trusts. None of the twelve statutes enacted to date mention the termination of trusts.

1131 Scotr $\$ 54.3$. In analyzing the Wilensky case Professor Scott states that the result seems right, "if it is found that the testator intended that the estate should be disposed of in accordance with the terms of the trust agreement even though he should revoke the trust thereby created." Palmer, Testamentary Disposition to the Trustee of an Inter Vivos Trust, 50 MrCr. L. REv. 33, 64 (1951), analyzes the Wilensky situation under two methods: incorporation and interpretation. Under the former, the court would probably hold, as in Wilensky, that the revocation, not being within the statutory methods for revoking a will, would be ineffective to revoke the will but effective to revoke the living trust. Under the second inethod, 
that this approach leaves much to be desired. In most cases it will be next to impossible to determine the testator's intent. Probably a testator would have had no specific intent in mind to operate in this set of facts. More likely he would merely have had an intent to revoke his living trust and would have given no thought to the effect of this revocation on his will, or he would have merely forgotten to change his will. It seems that the better approach would be to provide for this factual situation by legislative action. A statute would at least bring certainty into this troublesome and uncertain area. ${ }^{114}$

An analysis of the decided cases in the whole area of pour-over wills and living trusts, whether the decisions liave turned on the doctrine of incorporation by reference, on that of independent significance, or on some other theory or combination of theories, discloses a confused and confusing area of the law. It has been held that a gift by will to a revocable and amendable trust which has not been amended after the date of the will is valid, ${ }^{115}$ and on almost the same set of facts that it is invalid. ${ }^{116}$ It has been held that where the trust agreement was amended after the date of the will the attempted gift is wholly invalid; ${ }^{117}$ that it is valid but that the property conveyed by will can be held only under the terms of the trust agreement as it existed as of the date of execution of the will; ${ }^{118}$ and that the gift to the trust as it exists at the date of death is valid in all respects. ${ }^{110}$

interpretation, the first question to be answered by the court is, what was the intent of the testator when he inade the will? It seems that the writers see no solution to this problem without attempting to learn, or else guessing or presuming, what was the subjective intent of the testator.

114 Professor Scott, in his latest writing on this subject, Scott, Pouring Over, 97 Trusts \& Estates 189, (1958), has this to say: "The law as expressed in the cases is, however, not very clear. ... In view of the uncertainties as to the problem of pouring over, statutes have been enacted quite recently in a number of States."

115 Montgomery v. Blankenship, 217 Ark. 357, 230 S.W.2d 51 (1950); Wells Fargo Bank \& Union Trust Co. v. Superior Court, 32 Cal.2d 1, 193 P.2d 721 (1948); In the Matter of the Estate of Willey, 128 Cal. 1, 60 Pac. 471 (1900); State ex rel. Citizens Nat'l Bank v. Superior Court, 236 Ind. 135, 138 N.E.2d 900 (1956); In re Snyders Will, 125 N.Y.S.2d 459 (Surr. Ct. 1953).

${ }^{116}$ In re Jones, [1942] 1 Ch. 328, 1 All E.R. 642; cf. Clark v. Citizens Nat'l Bank, 38 N.J. Super. 69, 118 A.2d 108 (Ch. 1955), in which the gift was held imvalid on the basis that the trust was not fully created (trust property not delivered) until three days after the will was executed.

117 Atwood v. Rhode Island Hospital Trust Co., 275 Fed. 513 (1st Cir. 1921); President and Directors of Manhattan Co. v. Janowitz, 260 App. Div. 174, 21 N.Y.S. 2d 232 (2d Dep't 1940).

118 Old Colony Trust Co. v. Cleveland, 291 Mass. 380, 196 N.E. 920 (1935); Koeninger v. Toledo Trust Co., 49 Ohio App. 490, 197 N.E. 419 (1939) ; Bolles v. Toledo Trust Co., 144 Ohio St. 195, 58 N.E. 2d 381 (1944); In re Edwards' Will Trusts, [1948] Ch. 440.

119 Swetland v. Swetland, 102 N.J. Eq. 294, 140 Atl. 279 (Ct. Err. \& App. 1928); Matter of Ivic, 155 N.Y.S.2d 544 (Surr. Ct. 1956). The gifts were also beld valid where a codicil to the will was executed after the amendments to the trust in Continental Illinois Nat'l Bank v. Art Institute of Chicago, 409 IIl. 481, 100 N.E.2d 675 (1951); In re York's Estate, 95 N.H. 435, 65 A.2d 282 (1949); First Central Trust Co. v. Claflin, 49 Ohio App. 29, 73 N.E.2d 388 (1947). 
It has also been held that a gift by will to a trust which has been completely revoked after the will ,was executed is valid. ${ }^{120}$

\section{The Purposes of the Statutes of Wills}

The reasoning of the courts in many cases is difficult to accept. The decisions have turned upon various analyses of the statutes of wills. Many courts have frowned upon the pour-over device as an attempt by testators to evade the statute of wills. ${ }^{121}$

One sometimes wonders whether the courts have lost sight of the real purpose of the statute of wills. The decisions and opinions seem to wander through a maze of endlessly varying situations of testators and their wills, trying to make nice, neat syllogisms out of the countless variations of human desires, intents and acts which go into the making of a will. One is inclined to believe with Professor Palmer that "without adequate reason the law has departed too far from the common understanding of those whose activities it regulates." 122

The statutes of wills were designed to protect testators, not to frustrate them. They were based on a clear understanding of human needs and human conduct. They recognized that most people are good and honest and trusting-but also that some people are bad and dishonest and crafty. In order to protect the good from the bad in the cherished right of disposing of one's property by will the law has wisely laid down certain ground rules for the conduct of testators and their witnesses. ${ }^{123}$ This was done to reduce the risk of having false and fraudulent documents substituted for genume wills after the death of the testator. ${ }^{124}$

${ }^{120}$ Fifth Third Union Trust Co. v. Wilensky, 79 Ohio App. 73, 70 N.E. 2d 920 (1946).

121 Notes 49, 50 supra; Palmer, Testamentary Disposition to the Trustee of an Inter Vivos Trust, 50 Mrch. L. REv. 33, 69 (1951). Some writers have been as critical as the courts, Lauritzen, note 3 supra.

${ }_{122}$ Palmer, Testamentary Disposition to the Trustee of an Inter Vivos Trust, 50 MTcr. L. REv. 33 (1951).

1231 Scort \& 55.9: "In order, however, to prevent false claims, based on perjured testimony, the legislatures have provided that certain dispositions cannot be effectuated unless cvidenced in certain formal ways." In Matter of Rausch, 258 N.Y. 327, 333, 179 N.E. 755, 757 (1932), Judge Cardozo stated, "Much will depend upon the extent to which the door is likely to be opened to chicanery or mistake if there is relaxation of the requirement of self-sufficient integration."

124 We might speculate that the reasoning of the legislators as they enacted the various statutes of wills went somewhat as follows: if wills are required to be made in writing, are required to be signed by the testator in the presence of other persons who see him sign, if those other persons also are required to sign as witnesses, and the testator sees them sign and they see each other sign, then a situation bas been created where there is enough formality to fix these acts in the minds and memories of the witnesses; there are available at least two persons other than the testator who knew what transpirel on that date of signing, and who, if living after the death of the tesator, could probably give sufficient evidence of the facts surrounding the making and signing of the will so that the court could exclude the false and admit the genuine will, and thus capture the real wish, the real "will" of the testator. 


\section{The Execution of Wills and Trusts - A Comparison}

That is what the statute of wills was designed to do and that is all that it can do. Now let us compare the situation surrounding the signing of the usual will with that surrounding the signing of the usual living trust agreement, or an amendment to such an agreement. Are the facts and circumstances which are required by the statute of wills to be in existence at the signing of a will better designed to capture the intent of the testator and preserve the evidence of it than are the facts and circumstances which are generally in existence at the signing of a living trust agreement or amendment?

Testators know that a will is a revocable instrument, that it can be changed by them at any time, that it has no present effect on their property and will not have any effect until their death. The testator does not part with title to or possession of any of his property when he signs his will. ${ }^{125}$

A trust agreement or declaration of trust takes effect at once when it is signed. To have an effective trust it is necessary that some property be transferred to the trustee. ${ }^{126}$ The trustor or grantor knows that he must give away or part with title to and possession of some of his property immediately on signing his trust agreement. The original agreement and any amendments to it are usually signed by at least two persons, the trustor and trustee, before they become effective.

In the light of these facts, can it be said that the signing of a will is a more formal act than the signing of a living trust agreement; that there is less chance for fraud in the signing of a will than in the signing of a trust agreement; that the evidence is better preserved in the will situation (where the witnesses do not know the content of the will) than in the trust situation (where both trustor and trustee know the contents of the agreement); that the act of the trustor in presently parting with some of his property will be more lightly regarded than the act of the testator who parts with no property? The answer to these questions seems obvious.

There is also the ever present problem of the holographic will which is validated by statute without formal attestation in many states. By its very nature it is prepared by a layman who does not understand the precision of legal language or the niceties of the statute of wills. ${ }^{127}$ It is generally prepared in secret and often only the testator knows of its contents or even of its existence. It is often carelessly written and worded, may consist of many pages or papers not integrated in language, but physically attached, not bearing the same date and not found in the same place. Yet

125 ATrRnson § 1.

128 Clark v. Citizens Nat'l Bank, 38 N.J. Super. 69, 118 A.2d 108 (Ch. 1955) ; 1 Scorr §32.2. 127 In contrast, practically all voluntary trusts today are drawn by attorneys. 
this type of will is approved by statute in many states ${ }^{128}$ and the courts have often gone a long way in construing these statutes liberally in order to validate such wills. ${ }^{129}$ It is submitted that a legal system which has shown such a steadfast purpose in attempting to carry out the intent of testators in disposing of their property at death should have no difficulty in integrating the pour-over will and trust into this system.

It would appear that the validation of gifts by will to existing trusts in most of the situations described above is neither a relaxation nor a weakening of the effects of statutes of wills, nor a conscious or sinister or reprehensible attempt to avoid the desirable purposes for which the statute of wills was enacted. The pour-over device should be looked upon as a valuable and efficient method for the management and disposition of property in today's complex financial and business world. It can accomplish desirable results that can be achieved in no other way. ${ }^{130}$ Because of these facts it is looked upon by property owners, attorneys, trust officers, accountants, life underwriters and others in the estate planning field as one of the most valuable tools in estate planning. ${ }^{131}$ It is no doubt here to stay and will probably imcrease in popularity as it becomes more widely understood. For these reasons the courts and the legislatures should review and re-examine the pour-over device carefully, conscientiously and without prejudice.

\section{Legrslative Action as a Remedy}

It is, perhaps, unfortunate that in the early cases the courts felt constrained to attempt to force the pour-over device into the narrow confines of some of the older concepts in the law of wills. Since it did not always seem to fit smoothly, some courts rejected it. Because of these early decisions, it seems doubtful that the pour-over device can find its proper place in estate planning and estate administration by case law alone. Twelve

128 Atrinson \$ 75; Bordwell, Statute Law of Wills, 14 Iowa L. Rev. 1 (1928). Cax. Pro. CODE $\$ 53$ provides that "A holographic will is one that is entirely written, dated and signed by the hand of the testator himself. It is subject to no other form, and need not be witnessed. No address, date or other matter written, printed or stamped upon the document, which is not incorporated in the provisions which are in the handwriting of the decedent, shall be considered as any part of the will."

129 See Hanson, Holographic Wills, 95 Trusts \& Estates 875 (1956). Former Judge Hansen states, "During the four and one-half years that I sat in Los Angeles probate court, I do not recall many days that there were not at least 4 or 5 holographic wills offered for probate." Ibid. When it is considered that there are two judges assigned full time to the probate department, plus several branch courts having part time probate calendars, it appears that Los Angeles County may lead the nation in experience with holographic wills. Apparently writing holographic wills is a long-standing practice in Cahifornia. "If testators are to be encouraged by a statute like ours to draw their own wills, the courts should not adopt, upon purely technical reasoning, a construction which would result in invahidating such wills in half the cases." In the Matter of the Estate of Soher, 78 Cal. 477, 21 Pac. 8 (1889).

130 For reasons given for using the pour-over device, see text at note 5 supra.

131 Notes 2, 5 supra. 
states have now recognized this fact and have enacted laws which give legislative approval to gifts by will to existing trusts in some of the factual situations discussed above. ${ }^{132}$

The first statutes specifically approving a devise or bequest by will to an existing trust were enacted in 1953 by Connecticut ${ }^{133}$ and Indiana. ${ }^{134}$ In 1955 Illinois, ${ }^{135}$ North Carolina ${ }^{136}$ and Wisconsin ${ }^{137}$ enacted somewhat similar statutes. In 1957 Delaware, ${ }^{138}$ Nebraska,, ${ }^{139}$ Oregon, ${ }^{140}$ Pennsylvania $^{141}$ and Wyoming ${ }^{142}$ adopted statutes patterned somewhat after the earlier acts, and Connecticut amended its 1953 act. ${ }^{143}$ In 1958 Mississippi ${ }^{143 a}$ and Virginia ${ }^{144}$ adopted similar statutes.

\section{A. An Analysis of the Pour-Over Statutes}

All of the statutes lave the virtue of bringing a degree of certainty into this uncertain area. All statutes validate gifts to irrevocable trusts and to revocable and amendable trusts which have not been amended after the will was executed. ${ }^{144 a}$ Nine statutes, including those of Delaware, Illinois, Indi-

132 Professor Palmer should receive substantial credit for the legislation enacted in this field in the past few years. In his article in 50 Micr. L. REv. 33 (1951), he recommended that certainty be sought by legislation and set out a sample statute for consideration at 67-68. The earlier statutes enacted in Illinois and North Carolina were patterned after Professor Palmer's suggested form.

133 Conn. Gen. Laws 1953, ch. 442.

134 Ind. Laws 1953, ch.112, Ind. Star. ANn. \$ 6-601 (j) (Burns 1957).

135 III. Laws 1955, ILx. REv. Stat. ch. 3, § 194a (1957): "By a will signed and attested as provided in this Act a testator may devise and bequeath real and personal estate to a trustee of a trust which is evidenced by a written instrument in existence when the will is made and which is identified in the will, even though the trust is subject to amendment, modification, revocation or termination. Unless the will provides otherwise the estate so devised and bequeathed shall be governed by the terms and provisions of the instrument creating the trust including any amendments or modifications in writing made at any time before or after the making of the will and before the death of the testator." The Illinois act has served as a prototype in this new field and has been followed, with changes in language and some additions, in North Carolina, Delaware, Nebraska, Oregon and Wyoming (notes 136, 138-40, 142 infra).

136 N. Car. Laws 1955 , ch. $388, \S 1$, N. Car. Gen. Star. ch. 31 , $\$ 47$ (1957).

137 Wis. Laws 1955, ch. 85, § 231.205, WIs. Stat. Anv. $\$ 231.205$ (West 1957).

138 Del. Laws 1957 , ch. 125, 51 DEL. Laws ch. 1, Title 12, $\$$ III.

139 Neb. Laws 1957, L.B. 147, p. 390, NEB. Rev. StAт. § 30-1801 (1957).

140 Ore. Laws 1957, ch. 345, OrE. REv. STAT. ch. 114, § 114.070 (1957).

141 Pa. Laws 1957, Act. 378, Pa. Stat. Ann., tit. 20, 180.14 (Purdon 1957).

142 Wyo. Laws 1957, ch. 180, Wyo. Comp. Stat. ch. 6, § 6-310.

143 Conn. Gen. Laws 1957, ch. 575, Conn. Gen. Stat. $\$ 45-173$ (1958).

143a MIss. S.B. No. 1928, approved May 6, 1958.

144 Va. Laws 1958, ch. 450, § 64.71.1, VA. Code § 64-71.

144a See 57 Mrcm. L. REv. 81 (1958) for a detailed and critical analysis of ten of these statutes and the author's views as to how these statutes may be construed. The full text of the statutes of Conn., Ill., Ind., Miss., Neb., N. C., Ore., Pa., Wis. and Wyo. is set out in the appendix at $10 \%$. 
ana, Mississippi, Nebraska, North Carolina, Pennsylvania, Virginia and Wyoming, go to the heart of the principal problem raised by the cases and validate gifts by will to trusts which have been amended after the will was executed, stating that, unless the will provides otherwise, the property received by will shall be held under the terms of the living trust as it exists at the date of death of the testator. Oregon provides that the gift by will is valid only if the will or codicil was executed after any amendments to the living trust. Wisconsin provides that an amendment of the living trust shall have no effect on the property received by will unless the will is executed or republished after the amendment. ${ }^{145}$ Connecticut provides that the gift by will is invalid if the living trust is amended after the will or codicil is executed. ${ }^{146}$

\section{B. What Trusts May Receive Gifts by Will}

Eleven states ${ }^{147}$ have phrased their statutes in language broad enough to include living trusts created by the testator or by any other person and presumably trusts created by the will of another person. This is certainly a wise provision for making a workable statute, since there are and will be many cases where a testator will desire to leave his property to a living trust or a testamentary trust created by someone else, usually a family member. ${ }^{148}$ Connecticut is the only state which has adopted specific re-

145 The Wisconsin statute, note 137 supra, is a long and complex act dealing with the validity of revocable living trusts, powers reserved by the settlox, the excrcise of such powers, gifts by will to living trusts and widows statutory rights. Although it may be suited to the Wisconsin legislative system, it is the least desirable type of statute and is not recommended as a pattern for future legislation in other states.

146 The 1953 Connecticut statute, note 133 supra, was a short and clear act, following the plan of other statutes, but with the additional requirement that the trust agreement be witnessed as a will and limited to trusts created by the testator. The 1957 Connecticut statute, note 143 supra, is long and complex and brings in several elements and subjects not suggested by the cases discussed and not included in other statutes. Gifts are himited to trusts created by the testator and his immediate family, the formalities of a will are required for the trust agreement, the method of identifyimg the trust in the will is specifically spelled out, the gift is declared invalid if certain types of amendments to the trust are made after the will but not for other types, and the trust is declared to be non-testamentary only if the testator chooses a local trustee. This statute will severely limit Connecticut residents in their estate plans and may create inore problems than it settles.

147 Del., Inl., Ind., Miss., Neb., N. C., Ore., Pa., Va., Wis., Wyo.

148 The few cases dealing with the problems of gifts by will to a testamentary trust created by the will of another person, note 72 supra, have shown less concern over this type of gift than over a gift to a revocable living trust. There has been some doubt as to whether the trustee of a testamenatry trust in California could accept such gifts. In 1957 the Conference of State Bar Delegates adopted Resolution No. 9, proposing an amendment to Car. Prob. CodE $\$ 1120$, which would allow testamentary trustees, with court approval, to accept additions to the trust from sources other than the estate of the decedent. This later became part of the 1959 Legislative Program of the State Bar of Cahifornia and is now pending in the legislature as A.B. No. 2169, amending $\$ 1120$ and adding $\$ 1120.1$ to the Probate Code. At date of publlcation this bill is before the Judiciary Committee of the Assembly. 
strictions in this area, limiting the gift by will to living trusts executed with the same formality as a will, created by the testator, his spouse, his parent or his child. While this group may include most of those trusts to which testators might wish to make gifts by will, it is difficult to see why any restriction should be placed on testators in their choice of trusts to receive such gifts.

\section{The Effect of a Gift by Will on the Nature and Administration of the Living Trust}

In four states ${ }^{149}$ it is provided that, unless the will provides otherwise, the property received through the gift by will shall not be deemed held under a testamentary trust. This indicates that the property shall simply be added to the assets of the living trust and the living trust shall be administered exactly as it was prior to receipt of the gift. This is another wise provision which goes to the heart of the problem, since one of the primary purposes of testators in using this device is to avoid the restrictions of testamentary trust administration. ${ }^{150}$ Six statutes ${ }^{151}$ make no specific reference to this question, perhaps because the laws of these states do not create substantial differences between the administration of living trusts and testamentary trusts. Connecticut provides that the property received through the gift by will shall not be deemed held under a testamentary trust unless the trustee is a non-resident individual or corporate trustee. ${ }^{152}$ Nebraska

148 Miss., N. C., Pa., Va.

160 This is a problem which the courts have not recognized or have failed to pass upon in most of the cases. The clearest and most decisive answer that the property received by will is not held under a testamentary trust is that given by the Supreme Court of California in Wells Fargo Bank \& Union Trust Co. v. Superior Court, 32 Cal. 2d 1, 193 P.2d 721 (1948). In holding that the trust property received by will was not held under a testamentary trust, but merely augmented the biving trust, the court said, "The question remains, however, whether there is some established principle of law or reason of policy that would justify this court in regarding the (existing trust) as consisting of two trusts, regardless of the intention of the trustor. Petitioner lias not referred to any principle of law that prevents a trustor of an inter vivos trust from increasing the corpus of the trust by bequeathing or devising property for that purpose in his will. . . . No reason of policy lras been suggested why this court should regard the (existing trust) as two separate trusts contrary to the expressed intention of the trustor." Id. at 8, 193 P.2d at 726. Accord, State ex rel. Citizens Nat'l. Bank v. Superior Court, 236 Ind. 135, 138 N.E. 2d 900 (1956); In re York's Estate, 95 N.H. 435, 65 A.2d 282 (1948); Swetland v. Swetland, 102 N.J. Eq. 294, 140 Atl. 279 (Ct. Err. \& App. 1928) ; Matter of Rausch, 258 N.Y. 327, 179 N.E. 755 (1932); Matter of Ivie, 155 N.Y.S. 2d 544 (Surr. Ct. 1956).

161 Del., III., Ind., Ore., Wis., Wyo.

162 The Connecticut statute, note 143 supra, reads in part as follows: "Such reference in a will or codicil to such trust document by which a devise or bequest is made to such trust shall not thereby cause such trust or such part of the assets thereof distributed to it by such devise or bequest to be subject to the jurisdiction of the probate court in which such will or codicil is admitted to probate unless any trustee thereof resides or has its principal place of business outside of the state, in which event the provisions of such document of trust, if all other provi- 
goes one step further in restrictions and provides that, unless the will provides otherwise, the gift by will shall not be deemed held under a testamentary trust if the trustee is a resident corporate trustee. ${ }^{153}$

\section{Restrictions on the Choice of Trustees}

Connecticut ${ }^{154}$ and Nebraska ${ }^{155}$ chose an indirect method of invalidating gifts by will to non-resident trustees. Virginia chose the direct approach. ${ }^{150}$ It is unfortunate that three states have chosen to insert provisions in these desirable remedial statutes which restrict the trustor-testator in his estate planning and his choice of trustees. One can understand the economic motives behind these restrictions, the natural desire to keep the trust administration within the state of domicile. ${ }^{157}$ Yet it hardly seems equitable to penalize the property owner in order to accomplish this purpose. During his lifetime the trustor may select any trustee, individual or corporate, in any state to administer his living trust. No sound reason is apparent why he should not be allowed to add to this trust by a bequest or devise in his will at death. If he can make a gift by will directly to his children or grandchildren who may reside in another state, there is no sound reason why he should not be able to make a gift by will to the living trust which he has already established for them in that other state.

sions of this section have been complied with, shall be cleemed incorporated in such will or codicil, and such bequest or devise shall be administered as a testamentary trust under the continuing jurisdiction of the probate court in which such will or codicil is admitted to probate."

153 The Nebraska statute, note 139 supra, reads in part as follows: "Unless the will provides otherwise, the property so devised and bequeathed shall not be deemed held under a testamentary trust if the designated trustee is a corporate trustee authorized by law to act as an executor or administrator."

154 Note 152 supra.

155 Note 153 supra.

156 The Virginia statute, note 144 supra, reads in part as follows: "A devise or bequest in a will duly executed pursuant to the provisions of this Chapter may be made in form or substance to the trustee or trustees of a trust established in writing prior to the execution of such will, provided that at the testator's death at least one trustee of such trust is an individual resident of this state or is a corporation or association authorized to do a trust busmess in this state and provided further that a corporation or association not authorized to do a trust business in this state is not at the testator's death a trustee of such trust."

157 Of course these restrictions on this particular type of property distribution plan are merely a part of the broader field of the contest for probate and trust business and practice. See Bright, Permitting a Non-Resident to Choose Place of Probute, 95 Trusts \& Estates 865 (1956). It is natural for legisatures, lawyers and corporate fiduciaries of any state to desire to keep all of the assets of a resident decedent within their state for administration. A generation or two ago when property holdings were mostly local, when pcople were more stable in their residence and when estate plans were more simple that was the usual pattern. Today we have a more mobile population, people change states of residence not once but several timcs during their life, most sizable estates inelude interstate property holdings, and economic necessity has produced many new estate planning devices. To resist these trends is not fair to 


\section{E. The Effect of Revocation or Termination of the Living Trust on the Gift by Will}

Six statutes ${ }^{158}$ make no specific provision as to the effect of a complete revocation of the living trust on the gift by will. Six statutes ${ }^{159}$ specifically provide that revocation of the living trust shall invalidate the gift by will. No statute makes specific provision as to the effect of termination of the living trust on the gift by will. In the absence of legislative policy as contained in a statute, the courts will be left to decide this issue in each case on the facts involved, basing their decision on the supposed intent of the testator as gleaned from the documents involved or upon the courts' estimate of what is the most equitable disposition between the parties in each case.

One of the principles of will construction is that a testator is presumed not to have intended to die intestate as to any of his property. ${ }^{100}$ In a case where the gift to the living trust is contained in the residuary clause of the will, the courts may be expected to search for an intent or a theory upon which the gift may be held valid in order to avoid intestacy. ${ }^{161}$ Where the gift to the hiving trust consists of a specific item or a sum of money and the will contains an adequate residuary clause giving the residue to the natural objects of the testator's bounty, the courts may not be so hesitant in holding the gift to the revoked or terminated trust invalid since the gift would then pass under the residuary clause. Because of the many questions which are bound to arise in these situations it would seem preferable to have a legislative policy adopted by having a specific provision in the statute as to the effect of both revocation and termination.

\section{F. Alternative Disposition of the Property Where the Gift by Will is Held to be Invalid}

One final problem remains in this field and that is the ultimate disposition of the subject matter of the gift by will if the gift to the living trust is held to be invalid. None of the statutes enacted to date has mentioned or dealt with this problem. As stated above, where the gift consists of a specific item or a sum of money, it would normally be held to fall into the residue

the property owner and is probably not good public relations for the lawyer or the corporate fiduciary. It must be remembered that our will, probate and trust laws are enacted for the benefit of testators, trustors and beneficiaries. It is to be hoped that future legislation in this field will trend away from some of the restrictive laws of recent years and allow the trustortestator a large measure of freedom and flexibility im planning his estate.

158 Del., Ill., Ind., Ore., Wis., Wyo.

109 Conn., Miss., Neb., N. C., Pa., Va.

160 Atrnsson \$146; Palmer, Testamentary Disposition to the Trustee of an Inter Vivos Trust, 50 MrCH. L. REv. 33, 65 (1951).

101 Note 36 supra. 
of the estate and pass under the residuary clause. In most cases this result would probably not do violence to the testator's overall plan for the disposition of his estate and does not pose a serious problem.

In cases where the gift by will to the living trust is contained in the residuary clause-and this may represent nine out of ten cases-the problem is much more serious. If such a gift is held invalid, it appears that the court would have no alternative to holding that the residue of the estate passes as intestate property. In many cases this might represent the most equitable solution. It must be remembered that the laws of descent and succession were adopted to fit the average family situation where there is no effective disposition by will. In cases where the testator is also the trustor and has voluntarily revoked his own living trust it could be argued that he would prefer intestacy to having the property pass under the terms of the trust which he has revoked. ${ }^{162}$

In cases where the testator makes a gift by will to a living trust created by another person and this trust is revoked one could think of many situations where the testator might not desire to have the gift by his will lapse and pass as intestate property. So also where the living trust had not been revoked, but had terminated, perhaps unknown to or unremembered by the testator, he might still desire to have the gift follow the terms of the termimated trust into the hands of the remaindermen. These and other factual situations suggest that intestacy may not be the most desirable result of invalidating a gift by will to a living trust. ${ }^{103}$

\section{G. A Recommended Statute}

A review of the case law in this entire area indicates that the desired degree of certainty can be achieved only by statute. An analysis of the statutes recently enacted in twelve states indicates that only a statute which is specific and defmitive in most of the areas of doubt which are inherent in this field will achieve the desired degree of certainty. It is recommended that the proposed statute set out below be considered for adoption as part of the Probate Code of California: ${ }^{164}$

102 See discussions of the Wilensky case in 1 Scort $\$ 54.3$; Palmer, Testamentary Disposition to the Trustee of an Inter Vivos Trust, 50 MrCH. L. Rev. 33, 64 (1951).

103 See hypothetical cases set out in notes 111,112 supra.

164 This proposed statute was submitted to the Protiate Law and Procedure Committee of the Los Angeles Bar Association in June, 1958. With some minor changes in wording it was approved by that committee, by the Board of Trustees of the Los Angeles Bar Association, and became Resolution No. 30 of the 1958 Conference of State Bar Delegates. It was adopted by the Conference and referred by the Board of Governors of the State Bar to the Committee on Administration of Justice for study and report. At date of publication it does not appear that this committee's study and report will be completed in time for the proposed statute to be submitted to the 1959 session of the legislature. 


\section{Gifts, Devises and Bequests to Existing Trusts}

No gift, devise or bequest by will or codicil shall be invalid because it is made to a trust, or to the trustee of a trust, created prior to the death of the testator by a written instrument, not including the will of another person who survives the testator, and existing at the date of death of the testator, whether revocable or irrevocable and whether amendable or not amendable, and whether or not it has been amended after the date of execution of the will or codicil.

No such gift, devise or bequest to such an existing trust, or to the trustee of such a trust, shall create, or be construed as creating, a separate or testamentary trust, and shall not subject sucl existing trust to the laws relating to testamentary trusts, unless such trust was subject to such laws prior to the date of death of the testator.

Unless the will provides otherwise, property so given, devised or bequeathed by will shall be distributed to and received by the trustee of such an existing trust, and shall be held, administered and distributed by said trustee as part of such existing trust, under the terms and provisions of the trust instrument as it exists at the date of death of the testator.

Unless the will provides otherwise, a gift, devise or bequest by will to a trust, or to the trustee of a trust, which has been entirely revoked or has terminated prior to the date of death of the testator, shall be invalid and meffective to transfer the title to any property to such trust or trustee; and such property shall pass and shall be distributed to the persons who received the property of such trust on revocation or termination in the same proportions as they received property from such trust.

\section{ConCLUSIONS}

This proposed statute is not offered as a panacea for all of the problems in this field. It would bring to the law of California a higher degree of certainty in more of the areas of uncertainty than has been achieved by any of the statutes adopted in other states. It would leave some problems and questions to be decided by the courts on the specific factual situations involved as cases come up for review. It does not seem feasible to draft a statute which would attempt to solve all of these problems. It seems advisable to rely on that greatest of all teachers, experience, to show us the nature and scope of the many other problems which are bound to arise as individual cases involving pour-over wills and trusts reach the courts for review. ${ }^{185}$

$165 \mathrm{~A}$ final note of caution for trustor-testators and their professional advisers seems in order. An analysis of the cases in this field has convinced the writer that not all of the decisions turn solely on logic and precedent. As in any field where the property rights of widows are involved there is a lot of "fireside equity" in these decisions. Where a revocable hiving trust has been created by a married man and the bulk of his property transferred to it, the terms of that trust are always subject to severe scrutiny after his death. If the widow seems to have been deprived of some of the rights she would have had if he had retained ownership of the property the trust will probably be tested in court and its validity is at once jeopardized. The widow is always a favored hitigant and courts will guard her rights jealously. The hiving trust and pour-over will is no exception. For an example of how far a court will go in protecting a 
With the results of that experience, better statutes can be drafted and present statutes can be ainended to bring statutory certainty to this valuable field of estate planning.

widow's rights, see Bickers v. Shenandoah Valley Nat'l Bank, 197 Va. 145, 88 S.E.2d 889 (1955), 42 VA. I. Rev. 256 (1956). It is advisable to have these general concepts in mind in planning an estate, particularly when a revocable living trust is involved. If the plan as finally adopted gives the widow total economic benefits that are less valuable than her statutory rights, the wills and trusts stand a good chance of being attacked after denth and not too good a chance of surviving the attack. Pouring over is an excellent and useful device, but be sure when you pour that the widow has a favored place at the table and a sizeable cup to receive her share. 